\title{
White Bean seeds and Pomegranate peel and fruit seeds as hypercholesterolemic and hypolipidemic agents in albino rats
}

\author{
By E.A. Abdel-Rahim ${ }^{1}$, H.S. El-Beltagi ${ }^{1,2, *}$ and R.M. Romela ${ }^{1}$ \\ ${ }^{1}$ Biochemistry Dep., Faculty of Agriculture, Cairo University, P. Box 12613, Gamma st, Giza, Cairo-Egypt \\ ${ }^{2}$ Vice-Rectorate for Graduate Studies and Research, SUDLS, King Saudi University, Riyadh 11451 , \\ Kingdom of Saudi Arabia \\ * Corresponding author: Ibltg@yahoo.com
}

\section{RESUMEN}

Semillas de alubias blancas y piel y semillas de granadas como agentes hipercolesterolémicos e hipolipidémicos en ratas albinas

Se ha llevado a cabo un estudio para evaluar los efectos de las semillas de alubias blancas y de las de granadas así como de sus cáscaras secas y sus mezclas sobre los perfiles de lípidos de ratas que sufren de hiperlipidemia e hipercolesterolemia. La composición química de las alubias blancas y de las granadas (semillas y cáscaras) fue determinada en base a materia seca alcanzando una buena relación de proteínas, lípidos, fibra cruda y fenoles. Además, el contenido de fenoles de las semillas y las cáscaras de granada mostraron 16 compuestos que varían en cantidad entre ellos. Se observó que la catequina y los fenoles son los compuestos predominantes. Los resultados obtenidos mostraron un buen poder hipolipidémico de las semillas de alubias blancas y de granadas (semillas y las cáscaras), así como sus mezcla. Las semillas de alubias blancas en la dieta produjo una mejora general de la situación clínica, del perfil de lípidos en sangre (lípidos totales, triglicéridos, colesterol, HDL-C, LDL-C y VLDL-c), de la función hepática (ALT, AST y bilirrubina), de la función de los riñones (ácido úrico, urea y creatinina), de la peroxidación de lípidos en sangre y de las enzimas antioxidantes (SOD y CAT) por lo que se reduce la hiperlipidemia e hipercolesterolemia. La dieta mezcla presentó la mayor influencia sobre los estudios biológicos en relación con los otros tratamientos que utilizan solamente semillas de alubias blancas o granadas (semillas y cáscaras).

PALABRAS CLAVE: Alubia blanca (Phaseolus vulgaris L.) - Granada (Punica granatum) - Hipocolesterolemia - Hipolipidemia.

\section{ABSTRACT}

White Bean seeds and Pomegranate peel and fruit seeds as hypercholesterolemic and hypolipidemic agents in albino rats

This study was carried out to evaluate the effects of soaked white bean seeds, pomegranate seeds and dried peels and their mixtures on the lipid profiles of rats suffering from hyperlipidemia and hypercholesterolemia. The chemical compositions of dried soaked beans and pomegranate (seeds and peels) were determined on dry matter which amounted to good values for proteins, lipids, crude fiber and phenols. Also, the phenol contents of pomegranate seeds and peels showed 16 compounds varying in amount between them. It was noticed that catechin and phenol are the dominating compounds.
The obtained results showed a good hypolipidemic ability for soaked bean seeds and pomegranate (seeds, peels and their mixtures) as well as their mixtures. A bean seeds diet produced a general improvement in the clinical status of blood lipid profile (total lipids, triglycerides, cholesterol, HDL-c, LDL-c and VLDL-c), liver function (ALT, AST and bilirubin), kidneys function (uric acid, urea and creatinine), blood lipid peroxidation and antioxidant enzymes (SOD and CAT) by which hyperlipidemia and hypercholesterolemia were reduced. The mixed diet had the best influence concerning biological studies than the other treatments which used bean seeds and pomegranate (seeds and peels) alone.

KEY-WORDS: Hypocholesterolemia - Hypolipidemia Pomegranate (Punica granatum) - White bean (Phaseolus vulgaris L.).

\section{INTRODUCTION}

Lipid fractions are widely distributed in all cells of the body, but particularly in the nervous tissues. They play a major role in the functions of the mammalian body. They are required for the structural component of the plasma membrane of all cells and precursors for several factors of animal cells (hormones, bile salts and others). Hyperlipimia and atherosclerosis induced by a dietary fatty diet with cholesterol has been reported in several studies in animals (Lovejoy et al., 2002). The major contributors to cholesterol accumulation in arterial cells during the development of atherosclerosis include several factors such as a high level of plasma cholesterol (Murabito et al., 2005), inhibited blood paraoxonase (Li et al., 2006), enhanced macrophage cholesterol esterification rate (Aviram et al., 2000), in connection to the most effective factor which is increased oxidative stress (van Lieshout et al., 2003). Coronary atherosclerosis in primates not only resembles human lesions but can even produce myocardial infarction (McBride et al., 1998). From the clinical view point, there is a strong relationship between plasma lipid levels and atherosclerosis, particularly of the coronary arteries, which is of major importance. Atherosclerosis is a spectrum of arterial reactions that may result from many factors acting upon the vessel wall and producing their effect through different mechanisms and indifferent subjects which may vary significantly 
from one patient to another. Among the health hazards is the deterioration in lipid parameters in the body which leads to an incidence of atherosclerosis and cardiovascular diseases. According to the World Health Reports (WHPs, 2002), more than $75 \%$ of cardiovascular diseases are the world's leading cause of premature death, resulting from high blood cholesterol and other factors such as smoking, drinking alcohol and high blood pressure. Therefore, the studies need to look for natural compounds that can help the patient to get rid of or reduce the health hazards of the disease as a care that they receive (Turnbull, 2005). Phenols are one of the major groups of non-essential dietary compounds appearing in fruits and vegetables. Phenols have traditionally been considered as antinutritive compounds due to the adverse effect of one of their main compounds, tannins and protein digestibility. However, currently there is an increased interest in these compounds because they have been associated with the inhibition of atherosclerosis and cancer. The bioactivity of phenolic compounds may be related to their antioxidant behavior which is attributed to their ability to chelate metals, inhibit lipoxygenase and scavenge free radicals (MartinezValverde et al., 2000; Scalbert et al., 2005; El-Beltagi and Mohamed, 2010; Afify et al., 2011a). Oxidative stress produces a modification of DNA, protein and lipids by reactive oxygen species (ROS) and other free radicals which played a role in aging and diseases, including hyperlipidemia, atherosclerosis and cardiovascular diseases (El-Beltagi et al., 2008; Salama et al., 2009; Shehab et al., 2010; Afify et al., 2011b,c; El-Beltagi, 2011; El-Beltagi et al., 2011; Ibrahim et al., 2011; Afify et al., 2012a,b). Legume seeds utilized for human consumption have been of great interest to nutritionists and agricultural scientists for providing mankind with nutritional diets particularly when protein deficits occur. Bean seeds are not only a good choice for human nutrition but recently, the potential role of it in hyperlipidemia has received attention (Aly and El-Beltagi, 2010; Abdel-Rahim and El-Beltagi, 2011; Afify et al., 2012c). Several compounds with hyperlipidemic or hypercholesterolemic activity are found in relatively high concentrations in bean seeds (Abdel-Rahim and El-Beltagi, 2010). The present studies were undertaken to investigate the effect of pomegranate seeds and peels as well as bean seeds and their biological and nutritional evaluation though an animal experiment as follows:

1. Chemical composition of pomegranate seeds and peels as well as raw bean seeds.

2. The total phenolic levels and their constitute compounds of the pomegranate seeds and peels through analysis by HPLC technique.

3. The biological treatments of pomegranate seeds and peels as well as white bean seeds as hypolipidemic agents on blood analysis, i.e., glucose, lipid profile, liver function, kidney function, lipid peroxidation and enzymatic antioxidant (superoxide dismutase (SOD) and catalase (CAT) activity).

\section{MATERIALS AND METHODS}

\subsection{Preparation of samples}

The samples for the present study were purchased from a local market. White beans (Phaseolus vulgaris L.) were soaked in tap water $(1: 5 \mathrm{w} / \mathrm{v})$ for $12 \mathrm{~h}$ at room temperature. The soaked bean seeds were dried in a hot air oven maintained at $50^{\circ} \mathrm{C}$ according to the method of Jood et al. (1988). For pomegranate (Punica granatum) the samples were cut and the edible parts were separated from the peel, each of two parts (seeds and the peels) were dried in an air oven at $50{ }^{\circ} \mathrm{C}$ to complete dryness, and weighed to calculate moisture content. The samples were ground to a fine powder for analysis and for use in the animal experiments.

\subsection{General chemical analysis}

The determination of moisture, crude protein, total lipids, ash and crude fibers were made. A nitrogen-free extract was calculated by difference, deducing the percentage of ash, crude protein, total lipids and crude fibers from 100 according to A.O.A.C. (2000).

\subsection{Determination of total phenols}

The determination of total phenols was made according to the procedure described in the A.O.A.C. (2000) as tannic acid.

\subsection{HPLC analysis of pomegranate phenolic compounds}

The phenolic compounds of pomegranate samples were extracted according to the method described by Duke et al. (2003) in which a known weight of dried sample was extracted by methanol. Each phenolic compound was identified and subjected to the JASCO HPLC using hypersil $\mathrm{C}_{18}$ reversed phase column $(250 \times 4.6 \mathrm{~mm})$ with $5 \mu$ practical size. An injection by means of the Rheodyne injection value with 50 PJ fixed loop was used. A constant flow rate of $1 \mathrm{~mL} \mathrm{~min}^{-1}$ was used with two mobile phases: (A) $0.5 \%$ acetic acid in distilled water at $\mathrm{PH} 2,65$; and solvent (B) over 35 min, using a UV detector set at wavelength 245 $\mathrm{nm}$. The Phenolic compounds of the both samples were identified by comparing their retention times with those of the standard mixture chromatogram. The concentration of an individual compound was calculated on the basis of peak area measurements and then converted.

\subsection{Experimental animals}

Sprague - Dawley albino male rats weighing 65-75 g were used for the present study. The animals were obtained from the Agriculture 
Research Center (ARC), Giza, Egypt. The animals were raised in the animal house and kept under normal laboratory conditions (temperature remain $25 \pm 2{ }^{\circ} \mathrm{C}$ ) for $48 \mathrm{~h}$ before the initiation of the experiment. During this period, animals were allowed free access to water and a basal diet. Food consumption and body weight were monitored daily for each animal.

\subsection{Animal diet}

The control diet is designed as reported by Lane - Peter and Pearson (1971), with 15\% casein, 10\% corn oil, $5 \%$ cellulose, $4 \%$ salt mixture (Schneeman et al., 1989), 1\% vitamin mixture (Philip et al., 1993) and starch $65 \%$. The high fat diet was similar to the control diet but differed in more fat content which was $20 \%$ sheep fat, $2 \%$ cholesterol and $0.25 \%$ bile salts and starch $42.75 \%$.

\subsection{Experimental design}

After a period of adaptation (one week), 48 of the male albino rats were divided into two groups as following:

\section{Group I. Healthy, normal control group}

The rats were fed a normal diet (8rats) as healthy, normal control animals.

\section{Group II. Hyperlipidemic group}

The rats were fed a high fat with cholesterol diet for 4 weeks (40 rats). At the end of the feeding period, blood samples were taken from the suborbital vein to test for blood cholesterol levels. A high level of serum cholesterol was considered an indication of hypercholesterolemia. The hyperlipidemic rats of the second group were subdivided into 5 subgroups (8 rats each).

Subgroup 1. Rats were fed the high fat/high cholesterol diet without any treatment (Group 2: hyperlipidemic control).

Subgroup 2. Rats were fed the high fat/ high cholesterol diet with $10 \%$ dried beans at the expense of starch (Group 3: Bean group).

Subgroup 3. Rats were fed the high fat/high cholesterol diet with $10 \%$ dried pomegranate seeds at the expense of starch (Group 4: Pomegranate seeds group).

Subgroup 4. Rats were fed the high fat/high cholesterol diet with $10 \%$ dried pomegranate peels at the expense of starch (Group 5: Pomegranate peels group).

Subgroup 5. Rats were fed the high fat/high cholesterol diet with $10 \%$ mixture of beans, dried pomegranate seeds and peels by a ratio of $1: 1: 1$ at the expense of starch (Group 6: Mixture group).

At the end of the 10-week interval, the rats fasted overnight and then the animals were killed by decapitation. Blood samples were collected from each rat with EDTA and subjected to a centrifugation tube at $3000 \mathrm{rpm}$ to obtain the plasma which was kept in a deep freezer for the subsequent investigation.

\subsection{Blood biochemical analysis}

Determination of plasma glucose. Plasma glucose levels were determined enzymatic colorimetrically according to the method of Trinder (1969).

Liver function. For liver function, AST and ALT activities were determined colorimetrically according to the method of Reitman and Frankel (1957), also, the total bilirubin levels of plasma were determined according to the method described by Tietz (1995).

Kidney function. For kidney function, uric acid, and urea contents in plasma were determined colorimetrically according to the methods described by Caraway (1975) and the determination of plasma creatinine content was carried out colorimetrically according to the method described by Faulkner and King (1976).

Plasma lipid and lipoprotein profile. For plasma lipid profile, total lipid, total triglycerides and total cholesterol levels were determined colorimetrically according to the methods of Knight et al. (1972), Fossati and Prencipe (1982) and Allain et al., (1974) respectively. But for the lipoprotein profile in plasma, HDL-c and LDL-c levels were determined according to Warnick et al., (1983) and Bergmeyer (1985) respectively, but VLDL-c was calculated using the equation described by Fiedewald et al., (1972).

Lipid peroxidation. Lipid peroxide was determined according to the method of Ohkawa et al., (1979). Also, catalase (CAT) and superoxide dismutase (SOD) activities were determined according to the methods described by Aebi (1984) and Nishikimi et al. (1972) respectively.

Statistical analysis. All data pooled through the present study were preceded by General Linear Model procedures (GLM) of the statistical analysis system described in the SAS user's Guide (SAS Institute, 2000). The significance of differences among treatment groups were tested using the Waller - Duncan k-ratio (Waller and Duncan, 1969). All statements of significance were based on a probability of $\mathrm{P}>0.05$.

\section{RESULTS AND DISCUSSION}

Legumes and fruits play important roles in human nutrition since they are rich sources of protein, soluble dietary fibers, calories, certain minerals, vitamins and antioxidants. Regarding the soaking of beans, the protein digestibility of beans was improved which may be attributed not only to the removal/reduction of antinutrients but also to the structural disintegration of the native protein, including enzyme inhibitors and lectins, differential solubility of the individual oligosaccharides and their diffusion rates, phytase activity to break down phytic acid in seeds and the development of endogenous $\alpha$-galactosidas activity to diminish oligosaccharides (Afify et al., 2011d). This process not only improves the protein digestibility of beans 
but also increases the bioavailability of nutrients (Shimelis and Rakshit, 2007).

Wheat beans and pomegranate are considered famous legumes and fruits in Egypt. The chemical composition of bean seeds as well as dried pomegranate seeds and peels are shown in Table 1. It could be observed that beans and pomegranates (seeds and peels) are rich in protein, dietary fiber, elements and carbohydrates, but beans contain lower amounts of total phenols than dried pomegranate which were observed as 6-11 times the total phenols. The total phenols in dried pomegranate seeds and peels were 0.51 and $0.65 \%$ respectively, but for bean seeds were $0.11 \%$. These values for pomegranate are comparable to the values reported by Gil et al. (2000), and showed that pomegranates contain an appreciable antioxidant power relative to bean seeds. This means that the hypolipidemic effects of pomegranates (seeds and peels) were mainly related to the antioxidant agents, but related to protein for bean seeds. Recently, a special interest was given to legume protein and fruits antioxidants as good antilipidemic and anticholesterolemic agents. For this reason, the present studies analyzed the phenolic compounds of pomegranate methanol extract either for seeds or peels. The HPLC analysis of both fractions showed the presence of 12 compounds and 13 compounds in peel extracts varying in amount between both fractions (Table 2). The total known compounds in pomegranate seeds were $90.65 \%$ while, the total unknown compounds were $9.35 \%$, also the total known compounds of pomegranate peels were $93.42 \%$ while, the total unknown compounds were $6.58 \%$.

Table 1

Chemical composition of the white beans and pomegranate (seeds and peels) as (g $\left.100 \mathrm{~g}^{-1}\right)$ dry weight

\begin{tabular}{lccccccc}
\hline \multicolumn{1}{c}{ Samples } & Moisture & $\begin{array}{c}\text { Total } \\
\text { Proteins }\end{array}$ & $\begin{array}{c}\text { Total } \\
\text { Lipids }\end{array}$ & Ash & Crude fiber & $\begin{array}{c}\text { Nitrogen } \\
\text { free extract }\end{array}$ & $\begin{array}{c}\text { Total } \\
\text { phenols }\end{array}$ \\
\hline Raw beans & $8.09 \pm 1.01$ & $25.01 \pm 2.22$ & $1.08 \pm 0.05$ & $5.33 \pm 0.16$ & $7.01 \pm 0.66$ & $53.48 \pm 4.12$ & $0.11 \pm 0.01$ \\
$\begin{array}{l}\text { Pomegranate } \\
\text { seeds }\end{array}$ & $8.57 \pm 1.02$ & $13.15 \pm 0.52$ & $3.55 \pm 0.21$ & $9.72 \pm 0.67$ & $10.01 \pm 0.91$ & $55.0 \pm 2.74$ & $0.62 \pm 0.03$ \\
$\begin{array}{l}\text { Pomegranate } \\
\text { peels }\end{array}$ & $13.93 \pm 1.00$ & $14.00 \pm 0.61$ & $3.02 \pm 0.22$ & $15.01 \pm 0.72$ & $12.17 \pm 0.92$ & $41.87 \pm 2.11$ & $1.261 \pm 0.03$ \\
\hline
\end{tabular}

Values represent the mean $\pm \mathrm{SE}$ of triplicate determinations.

Table 2

Phenolic compound profiles in the methanolic extract of pomegranate seeds and peels

\begin{tabular}{|c|c|c|c|c|c|}
\hline \multirow{2}{*}{ No. } & \multirow{2}{*}{ Compounds } & \multicolumn{2}{|c|}{ pomegranate seeds } & \multicolumn{2}{|c|}{ pomegranate peels } \\
\hline & & mg $100 g^{-1}$ D.W. & $\%$ & $\mathrm{mg} 100 \mathrm{~g}^{-1}$ D.W. & $\%$ \\
\hline 1 & Catechin & 406 & 71.99 & 850 & 71.73 \\
\hline 2 & Caffeic acid & - & - & 9 & 0.76 \\
\hline 3 & Phenol & 110 & 20 & 274 & 23.12 \\
\hline 4 & Daidzin & 4 & 0.71 & 5 & 0.42 \\
\hline 5 & Salicylic acid & 14 & 2.48 & - & - \\
\hline 6 & Ferulic acid & - & - & 5 & 0.42 \\
\hline 7 & p-Coumaric acid & - & - & 14 & 1.18 \\
\hline 8 & Daidzein & 1 & 0.18 & - & - \\
\hline 9 & Quercetin & - & - & 5 & 0.42 \\
\hline 10 & Genistein & 8 & 1.42 & 5 & 0.42 \\
\hline 11 & Cinnamic acid & 4 & 0.71 & 2 & 0.17 \\
\hline 12 & Kaempferol & 3 & 0.53 & 3 & 0.25 \\
\hline 13 & Eugenol & 4 & 0.72 & 2 & 0.17 \\
\hline 14 & Chrysin & 1 & 0.18 & 2 & 0.17 \\
\hline 15 & Galangin & 1 & 0.18 & 2 & 0.17 \\
\hline 16 & Pinostrobin & 7 & 1.24 & - & - \\
\hline
\end{tabular}


It was noticed that compounds such as catechin, phenol, daidzin, genistein, cinnamic acid, kaempferol, eugenol, chrysin and galangin are detected in the extracts from pomegranate seeds and peels. On the other hand, more than the phenolic compounds salicylic acid, daidzein, and pinostrobin were detected in the seed extract, but in the peels, caffeic acid, ferulic, $p$-coumaric acid and quercetin were identified. Catechin is dominating which amounted to about $72 \%$ of the total phenolic compounds and phenol amounted to about $20 \%$ or more for seed and peel methanolic extracts respectively. Both fractions of pomegranate showed good values when total phenols were determined in terms of tannic acid. The pattern of the HPLC analysis seems to be in agreement with (Li et al., 2006). It is clear that these phenolic compounds detected in pomegranate (seeds and peels) are responsible for the antioxidant effect and cholesterol lowering action. Pomegranate is one of these food items which are believed to possess strong antioxidant properties, including its capability to scavenge or prevent several reactive oxygen species and inhibit lipid peroxidation (Kaplan et al., 2001 and Li et al., 2006). The hypolipidemic effect may be due either to the retarding effect on lipid fraction absorption or the increase in the LDL receptor mediated cholesterol rein oval.

The studies are considered to be treatment investigations which were done on male albino rats weighing $70 \pm 5$. The results of the evaluation of the three studies samples as hypocholesterolemic and hypolipidemic agents in albino rats were statistically analyzed and summarized in Table 3 which presented the lipid and lipoprotein profiles of six groups at the end of the experimental period (10 weeks). The data pointed out a significant increase in total lipids, cholesterol and triglycerides when rats were fed the high fat/cholesterol diet, the values amounted to $2.19,2.80$ and 2.49 fold respectively in comparison to that of the normal control. The results presented in Table 3 show the effect of the administration of $10 \%$ beans and pomegranate (seeds and peels) as well as their mixture on the lipid profile of hyperlipidemic animals. In the case of hypolipidemic animals, the feeding of the different treatments (beans and pomegranate, seeds and peels, as well as their mixture) exhibited different effects on the blood lipid profiles and four treatments significantly alleviated the harmful effects of hypolipidemia where the mixture and bean treatments were the most effective as hyperlipidemic and hypocholesterolemic agents. On the other hand, the mixture of pomegranate seeds and peels and beans treatment possessed remarkable hypolipidemic and hypocholesterolemic activity but the levels of total lipids, cholesterol and triglycerides in blood were still higher than that of the control. The feeding of pomegranate seeds and peels produced the same alleviated effect on hypolipidemia and hypocholesterolemia. The results are in agreement with those data of blood lipoprotein contents of the present study (table 3) except for the HDL-cholesterol (HDL-c). The effects of pomegranate (seeds and peels) and beans as well as their mixture treatments on hyperlipidemic animals were also different. Hyperlipidemia increased blood HDL-c. LDL-C, VLDL-C contents, but the increase in HDL-c was lower than the increases in LDL-c and VLDL-C. This drastic effect of hyperlipidemia was improved by the present treatments whereas, greater increases in the HDL-C content in the blood of hyperlipidemic animals were observed after treatments with feeding beans, pomegranate (seeds and peels) and their mixture.

Table 3

Plasma lipid fractions and lipoprotein profile $\left(\mathrm{mg} \mathrm{dL}^{-1}\right)$ in experimental rats

\begin{tabular}{|c|c|c|c|c|c|c|}
\hline \multirow[b]{2}{*}{ Groups } & \multicolumn{6}{|c|}{$\mathrm{mg} \mathrm{dL}^{-1}$} \\
\hline & Total lipid & Triglycerides & $\begin{array}{c}\text { Total } \\
\text { cholesterol }\end{array}$ & HDL-c & LDL-c & VLDL-C \\
\hline $\begin{array}{l}\text { Group } 1 \\
\text { Normal control }\end{array}$ & $270.0 \pm 21.0^{c}$ & $74.0 \pm 4.21^{\mathrm{c}}$ & $65.0 \pm 2.14^{c}$ & $34.0 \pm 2.00^{\circ}$ & $26.0 \pm 1.72^{c}$ & $15.0 \pm 0.99^{c}$ \\
\hline $\begin{array}{l}\text { Group } 2 \\
\text { Hyperlipidemic control }\end{array}$ & $590.0 \pm 25.0^{\mathrm{a}}$ & $183.0 \pm 8.92^{\mathrm{a}}$ & $182.0 \pm 7.23^{a}$ & $44.0 \pm 2.74^{b}$ & $86.0 \pm 2.42^{a}$ & $37.0 \pm 2.00^{a}$ \\
\hline $\begin{array}{l}\text { Group } 3 \\
\text { Raw beans }\end{array}$ & $310.0 \pm 20.0^{c}$ & $81.0 \pm 5.24^{c}$ & $80.0 \pm 3.23^{b}$ & $46.0 \pm 3.11^{b}$ & $28.0 \pm 1.83^{c}$ & $16.0 \pm 1.00^{c}$ \\
\hline $\begin{array}{l}\text { Group } 4 \\
\text { Pomegranate seeds }\end{array}$ & $351.0 \pm 19.0^{b}$ & $98.0 \pm 4.49^{b}$ & $87.0 \pm 4.17^{b}$ & $49.0 \pm 2.19^{a}$ & $31.0 \pm 1.41^{b}$ & $20.0 \pm 1.21^{b}$ \\
\hline $\begin{array}{l}\text { Group } 5 \\
\text { Pomegranate peels }\end{array}$ & $349.0 \pm 21.0^{b}$ & $94.0 \pm 5.31^{b}$ & $86.0 \pm 3.92^{b}$ & $45.0 \pm 3.01^{b}$ & $32.0 \pm 2.00^{b}$ & $19.0 \pm 1.02^{b}$ \\
\hline $\begin{array}{l}\text { Group } 6 \\
\text { Mixture }\end{array}$ & $300.0 \pm 21.0^{c}$ & $78.0 \pm 4.11^{\mathrm{c}}$ & $86.0 \pm 4.01^{b}$ & $47.0 \pm 2.02^{\mathrm{ab}}$ & $27.0 \pm 1.46^{c}$ & $16.0 \pm 0.98^{c}$ \\
\hline LSD 5\% & 29.42 & 9.12 & 4.35 & 3.26 & 2.53 & 1.85 \\
\hline
\end{tabular}

Each value represents the mean of 8 rats (Means $\pm S E$ ).

The same letters in each column represent insignificant difference at $\mathrm{P}<0.05$. 
In contrast, the LDL-c and VLDL-c contents in the blood of the hyperlipidemic rats were significantly alleviated by the present treatments which were reduced but the levels were still higher than that of the control animals. These effects are indicative of a lower rate of lipid oxidation and show that the treated diets could exert antioxidant influences on lipid compartments of the lipidemic animals. The potent antioxidant activity of pomegranate was reported by Aviram et al. (2000) and Murthy et al. (2002) and may also contribute to the reducing effect of pomegranate on the high blood cholesterol accumulation, which is indicative of cholesterol accumulation in the retrial cell and the development of atherosclerosis (Singh et al., 2001). The elevated HDL-c is indicated by the stimulation of paroxonase activity which is associated with HDL-C and protected it from oxidation (Aviram et al., 2000). From the present results the hypolipidemic and hypocholesterolemic effects of the different treatments can be arranged in the following increasing order:

\section{Mixture $\geq$ Soaked bean seeds $>$ pomegranate seeds $\geq$ pomegranate peels}

The improvement in the lipid profile of blood could be attributed to several factors. The amino acids in protein, dietary fibers and antioxidants may play an important role in this action. The beneficial treatment of bean seeds and pomegranate (seeds and peels) showed that the dietary fibers have the potential to lower the levels of total cholesterol and LDL-C in blood. The absorption of bile salts by soluble dietary fibers (SDF) results in changes in cholesterol metabolism, loss in cholesterol and unavailability of bile salts in the intestine for micelle formation, which inhibits lipid fraction absorption; increased fecal bulk dilutes bile acids in the lower intestinal tract; and the short chain fatty acids produce propionate, which has been proposed to inhibit hepatic cholesterol synthesis (Tharanathan and Mahadevamma, 2003). Also, the amino acids in the present dietary food are used as precursors of lipoprotein, including HDL-c which accounts 50\% of its structural protein (Elliott and Elliott, 2001), which, via protein biosynthesis and also the three hypophseal peptides, stimulate fatty acids released from adipose tissue for their biodegradation (Campbell, 1995). In addition, these amino acids are considered lipotropic factors used in the protein biosynthesis of $\beta$-oxidation enzymes, glucose oxidase, antioxidant enzymes (SOD and CAT) and other protein factors. These enzymes stimulate the fat oxidation rate, antioxidative power, suggesting that dietary protein exerts its hypolipidemic effects by stimulating the $\beta$-oxidation fatty acids at the expense of fatty acids esterification (Wang and Jones, 2004).

The effects of the present antilipidemic agents on liver and kidney functions in hyperlipidemic rats were statistically analyzed and are illustrated in table (4). The results showed that hypolipidemia and hypocholesterolemia significantly stimulated ALT and AST activity as well as the plasma content of bilirubin. The same trend was observed for ALT and AST compared to the healthy control. These stimulations of AST activity indicated slight liver cell necrosis and the magnitude of increase correlated with the extent of necrosis (Murray et al., 2006). All the treatments with beans and pomegranate (seeds and peels) as well as their mixture (as hypolipidemic agents) in diseased animals were characterized by an alleviation and normalization in the both transaminase activities (ALT and AST) and bilirubin content in plasma. These are conflicting reports on the changes in blood. Alterations in transaminases

Table 4

Liver $\left(U \mathrm{~L}^{-1}\right)$ and kidney $\left(\mathrm{mg} \mathrm{L}^{-1}\right)$ functions in experimental rats

\begin{tabular}{|c|c|c|c|c|c|c|}
\hline \multirow{2}{*}{ Groups } & \multicolumn{2}{|c|}{$U L^{-1}$} & \multicolumn{4}{|c|}{$\mathrm{mg} \mathrm{dL}^{-1}$} \\
\hline & ALT & AST & Bilirubin & Urea & Uric acid & Creatinine \\
\hline $\begin{array}{l}\text { Group } 1 \\
\text { Normal control }\end{array}$ & $141.0 \pm 5.64^{b}$ & $42.0 \pm 3.23^{b}$ & $0.42 \pm 0.03^{d}$ & $57.0 \pm 3.15^{b}$ & $3.55 \pm 0.20^{c}$ & $0.66 \pm 0.04^{c}$ \\
\hline $\begin{array}{l}\text { Group } 2 \\
\text { Hyperlipidemic control }\end{array}$ & $176.0 \pm 3.99^{a}$ & $55.0 \pm 3.74^{a}$ & $0.71 \pm 0.04^{a}$ & $70.0 \pm 4.54^{\mathrm{a}}$ & $5.01 \pm 0.35^{a}$ & $0.90 \pm 0.05^{a}$ \\
\hline $\begin{array}{l}\text { Group } 3 \\
\text { Raw beans }\end{array}$ & $144.0 \pm 5.86^{b}$ & $46.0 \pm 3.00^{b}$ & $0.54 \pm 0.03^{c}$ & $60.0 \pm 2.99^{b}$ & $4.44 \pm 0.30^{b}$ & $0.69 \pm 0.04^{c}$ \\
\hline $\begin{array}{l}\text { Group } 4 \\
\text { Pomegranate seeds }\end{array}$ & $153.0 \pm 8.41^{b}$ & $45.0 \pm 2.79^{b}$ & $0.60 \pm 0.02^{b}$ & $62.0 \pm 3.16^{b}$ & $4.30 \pm 0.31^{b}$ & $0.78 \pm 0.02^{b}$ \\
\hline $\begin{array}{l}\text { Group } 5 \\
\text { Pomegranate peels }\end{array}$ & $157.0 \pm 7.94^{\mathrm{b}}$ & $46.0 \pm 3.24^{b}$ & $0.53 \pm 0.03^{c}$ & $61.0 \pm 3.00^{b}$ & $4.25 \pm 0.29^{b}$ & $0.77 \pm 0.05^{b}$ \\
\hline $\begin{array}{l}\text { Group } 6 \\
\text { Mixture }\end{array}$ & $143.0 \pm 7.11^{\mathrm{b}}$ & $44.0 \pm 2.77^{b}$ & $0.50 \pm 0.02^{c}$ & $61.0 \pm 2.78^{b}$ & $4.01 \pm 0.31^{\mathrm{bc}}$ & $0.75 \pm 0.03^{b}$ \\
\hline LSD 5\% & 8.85 & 3.95 & 0.05 & 4.43 & 0.34 & 0.04 \\
\hline
\end{tabular}

Each value represents the mean of 8 rats (Means $\pm S E$ ).

The same letters in each column represent insignificant difference at $\mathrm{P}<0.05$. 
activity and bilirubin contents in plasma have been thought to be significant in the pathogenesis of lipidemia and cholesterolemia. The increases in plasma bilirubin and stimulation in transaminases activity is unlikely to be due to damage in the liver and RBCs (Chatterjea and Shinde, 2002).

The treatment with the present antilipidemic agents was characterized by normalization in both transaminase activity and bilirubin content in the plasma of diseased animals. The effects of the present treatments on the kidney function of hyperlipidemic animals were confirmed by the determination of blood uric acid, urea and creatinine which were statistically analyzed. The data in table (4) show that hyperlipidemia and hypercholesteremia caused a significant increase in uric acid, urea and creatinine contents in the diseased animal blood. The treatments with beans, pomegranate (seeds and peels) and their mixture as lipotropic factors for present diseased rats produced a significant improvement in the three parameters of kidney function. The highest treatment effect on kidney function was detected by the mixture. The feeding of beans, pomegranate (seeds and peels) produced lower improved effects in the same respect. These effects were similar to those of the liver function.

The results presented in Table 5 indicate the hyperlipidemia effects on blood glucose, lipid peroxidation and enzymatic antioxidant (SOD and CAT) activity in blood which were statistically analyzed. These results show that hyperlipidemia did not change the values of blood glucose levels which were around the normal value for all treatments compared to the healthy control animals. Also, the present data show that the activities of SOD and CAT were significantly inhibited by lipidemia or cholesterolemia. In contrast, the data reveal that there is a significant increase in plasma lipid peroxide value in the diseased animals. Also, the results of Table 5 point out that the feeding of antioxidant diets (beans, pomegranate seeds and peels) and their mixture caused an improvement in blood peroxide values. Also, the present antioxidant diets alleviated the harmful effects of hyperlipidemia on SOD and CAT activities. These values were still far from that of normal healthy control animals.

The antioxidative action of pomegranate is suggested to be due to the capacity of phenols to transfer electron anion free radicals, chelate metal catalyst, active antioxidative enzymes as reported in the present studies and inhibit oxidases (Spencer et al., 2001). Therefore, the peripheral mechanism of action of the present treatments especially the mixture of dried pomegranate (seeds and peels) and bean seeds may be the main activity responsible for the antilipidemic activity of protein and antioxidants, although other target organs (liver and kidneys) cannot be discarded. The more pronounced effect of the mixture than the others alone may be due to the synergetic effect of the three diets, each of which produced a good alleviation and improvement in the lipidemic drastic effects as antilipidemic and anticholesterolemic agents influenced the blood lipid profiles. This may be due to the fact that the mixture consisted of lipotropic factors such as bean seed protein and antioxidative agents such as phenolic compounds of dried pomegranate (seeds and peels). This suggestion is confirmed by the observations of the present results, which show that the biological activity has been attributed to two main factors (lipotropic and antioxidant factors) either alone or synergistically. The present results are in harmony with each other.

Table 5

Plasma glucose, lipid peroxidation $\left(\mathrm{mg} \mathrm{dL}^{-1}\right)$ as well as SOD and CAT activities $\left(\mathrm{U} \mathrm{mL}^{1}\right)$ in experimental rats

\begin{tabular}{|c|c|c|c|c|}
\hline \multirow{2}{*}{ Groups } & \multicolumn{2}{|c|}{$\mathrm{mg} \mathrm{dL}^{-1}$} & \multicolumn{2}{|c|}{$\mathrm{U} \mathrm{mL}^{-1}$} \\
\hline & Glucose & Lipid peroxidation & SOD & CAT \\
\hline $\begin{array}{l}\text { Group } 1 \\
\text { Normal control }\end{array}$ & $100.0 \pm 4.42^{b}$ & $2.00 \pm 0.15^{c}$ & $490.0 \pm 18.0^{a}$ & $10.0 \pm 0.52^{a}$ \\
\hline $\begin{array}{l}\text { Group } 2 \\
\text { Hyperlipidemic control }\end{array}$ & $119.0 \pm 5.52^{\mathrm{a}}$ & $5.01 \pm 0.29^{a}$ & $125.0 \pm 10.0^{e}$ & $2.01 \pm 0.14^{d}$ \\
\hline $\begin{array}{l}\text { Group } 3 \\
\text { Raw beans }\end{array}$ & $99.0 \pm 4.12^{b}$ & $2.49 \pm 0.14^{b}$ & $389.0 \pm 17.0^{b}$ & $6.97 \pm 0.41^{c}$ \\
\hline $\begin{array}{l}\text { Group } 4 \\
\text { Pomegranate seeds }\end{array}$ & $107.0 \pm 4.97^{b}$ & $2.51 \pm 0.16^{b}$ & $269.0 \pm 14.0^{d}$ & $6.66 \pm 0.40^{c}$ \\
\hline $\begin{array}{l}\text { Group } 5 \\
\text { Pomegranate peels }\end{array}$ & $104.0 \pm 3.91^{b}$ & $2.36 \pm 0.17^{b}$ & $221.0 \pm 15.0^{d}$ & $6.02 \pm 0.37^{c}$ \\
\hline $\begin{array}{l}\text { Group } 6 \\
\text { Mixture }\end{array}$ & $104.0 \pm 3.23^{b}$ & $2.22 \pm 0.12^{c}$ & $300.0 \pm 19.0^{c}$ & $8.71 \pm 0.51^{b}$ \\
\hline LSD 5\% & 5.63 & 0.25 & 21.0 & 0.54 \\
\hline
\end{tabular}

Each value represents the mean of 8 rats (Means $\pm S E$ ).

The same letters in each column represent insignificant difference at $\mathrm{P}<0.05$. 
Thus the stimulation of transaminase activity and bilirubin content were used largely in the blood of the rats studied as indicators of liver function. Also, blood uric acid, urea and creatinine confirmed each other and previous findings.

From the present results it can be reported that the use of beans as therapy food against lipidemia and cholesterolemia, which had greatly improved effects on lipid profile, lipoprotein profile, lipid peroxidation, antioxidant enzyme activity, kidney functions and liver functions in the blood. Also, both dried pomegranate seeds and peel treatments improved and alleviated the harmful effects of hyperlipidemia and hypercholesterolemia. This rendered several studies to look for food rich in protein and antioxidants that can be preventive against atherosclerosis among exposed individuals. Therefore, further studies are required to evaluate the biochemical effects and mechanisms of the lipotropic factors studied and the antioxidant agents which may be used in food as recommended hypolipidemic food additives.

\section{REFERENCES}

Abdel-Rahim EA, El-Beltagi HS. 2010. Constituents of apple, parsley and lentil edible plants and their therapy treatments for blood picture as well as liver and kidneys functions against lipidemic disease. Electron. J. Environ. Agric. Food Chem. 9, 11171127.

Abdel-Rahim EA, El-Beltagi HS. 2011. Alleviation of hyperlipidimea in hypercholesterolic rats by lentil seeds and apple as well as parsley as semi-modified diets. Adv. Food Sci. 33, 1-6.

Aebi H. 1984. Catalase in vitro. Methods in Enzymol. 105, 121-126.

Afify AMR, Rashed MM, Ebtesam AM, El-Beltagi HS. 2011a. Effect of gamma radiation on protein profile, protein fraction and solubility of three oil seeds. Not. Bot. Horti. Agrobo. 39, 90-98.

Afify AMR, El-Beltagi HS, Fayed SA, Shalaby EA. 2011b. Acaricidal activity of successive extracts from Syzygium cumini L. Skeels (Pomposia) against Tetranychus urticae Koch. Asian Pac. J. Trop. Biomed. 1, 359-364.

Afify AMR, Shalaby EA, El-Beltagi HS. 2011c. Antioxidant activity of aqueous extracts of different caffeine products. Not. Bot. Horti. Agrobo. 39, 117-123.

Afify AMR, El-Beltagi HS, Abd El-Salam SM, Omran AA. 2011d. Bioavailability of iron, zinc, phytate and phytase activity during soaking and germination of white sorghum varieties. PLoS One 6, e25512, 1-7.

Afify AMR, El-Beltagi HS, Aly AA, El-Ansary AE. 2012a. Antioxidant enzyme activities and lipid peroxidation as biomarker for potato tuber stored by two essential oils Caraway and Clove and its main component Carvone and Eugenol. Asian Pac. J. Trop. Biomed. 2, S772-S780.

Afify AMR, El-Beltagi HS, Abd El-Salam SM, Omran AA. $2012 b$. Biochemical changes in phenols, flavonoids, tannins, vitamin E, $\beta$-carotene and antioxidant activity during soaking of three white sorghum varieties. Asian Pac. J. Trop. Biomed. 2, 203-209.

Afify AMR, El-Beltagi HS, Abd El-Salam SM, Omran AA. 2012c. Protein solubility, digestibility and fractionation after germination of sorghum varieties. PLoS One 7, e31154, 1-6.

Allain CC, Poon LS, Chan CS, Richamand W, Fu PC. 1974. Enzymatic determination of total serum cholesterol. Clin. Chem. 20, 470-473.

Aly AA, El-Beltagi HES. 2010. Influence of ionizing irradiation on the antioxidant enzymes of Vicia faba $\mathrm{L}$. Grasas Aceites 61, 288-294.

A.O.A.C. 2000. Official Methods of Analysis of Association of Official Analytical Chemists. $17^{\text {th }}$ ed. Washington D.C., USA.

Aviram M, Dornfeld L, Rosenblat M, Volkova N, Kaplen M, Hayek T. 2000. Pomegranate juice consumption reduces oxidative stress, low density lipoprotein modifications and platelet aggregation: studies in the atherosclerosis apolipoprotein E-deficient mice and in humans. Am. J. Clin. Nutr. 71, 1062-1076.

Bergmeyer HV. 1985. Methods of Enzymatic Analysis. Val. VIII $3^{\text {rd }} .154-160$.

Campbell MK. 1995. Biochemistry ( $2^{\text {nd }}$ ed) Saunders College Publishing, Philadelphia, USA..

Caraway WT. 1975. Standard methods of clinical chemistry. Academic press. New York and London. 4, 239-245.

Chatterjea MN, Shinde R. 2002. Text book of medical biochemistry. Jaypee Brathers Medical Publishers. New Delhi.

Duke SO, Rimando AM, Paco PF, Reddy KN, Semeda RJ. 2003. Isoflavone, glyphosate, and aminomethylphosphonic acid levels in seeds of glyphosate-treated, glyphosate-resistant soybean. J. Agric. Food Chem. 51, 350-364.

El-Beltagi HES, Salama ZA, El-Hariri DM. 2008. Some biochemical markers for evaluation of flax cultivars under salt stress conditions. J. Nat. Fibers 5, 316-330.

El-Beltagi HS, Mohamed AA. 2010. Changes in non protein thiols, some antioxidant enzymes activity and ultrastructural alteration in radish plant (Raphanus sativus L.) grown under lead toxicity. Not. Bot. Hort. Agrobot. Cluj. 38, 76-85.

El-Beltagi HES. 2011. Effect of roasting treatments on protein fraction profiles, some enzyme activities of Egyptian peanuts. Int. J. Food Sci. Nutr. 62, 453-456.

El-Beltagi HS, Ahmed OK, El-Desouky W. 2011. Effect of low doses $\gamma$-irradiation on oxidative stress and secondary metabolites production of Rosemary (Rosmarinus officinalis L.) callus culture. Radiat. Phys. Chem. 80, 965-973.

Elliott WH, Elliott DC. 2001. Biochemistry and Molecular Biology $\left(2^{\text {nd }}\right.$ ed.), Oxford University Press, Oxford, UK.

Faulkner NR, King JW. 1976. Fundamental of clinical chemistry. 2nd ed. Tietz editor. Saunders Philadelphia. 994-998.

Fiedewald WT, Levy LI, Fredrickson DS. 1972. Estimation of concentration of low density lipoprotein cholesterol in plasma without use of the preparative ultracentrifuge. Clin. Chem. 18, 499-502.

Fossati P, Prencipe I. 1982. The determination of triglyceride using enzymatic methods. Clin. Chem. 28, 2077-2080.

Gil M, Tomas-Barberan FA, Hess-Pierce B, Holcroft DM, Kader AA. 2000. Antioxidant activity of pomegranate juice and its relationship with phenolic composition and processing. J. Agr. Food Chem. 48, 4581-4589.

Ibrahim NM, Eweis EA, El-Beltagi HS, Abdel-Mobdy YE. 2011. The effect of lead acetate toxicity on experimental male albino rat. Biol. Trace Elem. Res. 144, 1120-1132. 
Jood S, Chauhan BM, Kappoor A. 1988. Contents and digestibility of carbohydrates of chickpea and black gram. Food Chem. 30, 113-127.

Kaplan M, Hayek T, Razz A, Coleman R, Dornfeld L, Vaya J, Aviram M. 2001. Pomegranate juice supplementation to atherosclerotic mice reduces macrophage lipid peroxidation, cellular cholesterol accumulation and development of atherosclerosis. $J$. Nutr. 131, 2082-2089.

Knight JA, Anderson SJ, Rawle JM. 1972. Chemical basis of the sulfophosphovanillin reaction for estimating serum total lipids. Clin. Chem. 18, 723-725.

Lane-Peter W, Pearson AE. 1971. Dietary require. In: "The laboratory animal principles and practice". Academic Press London and New York.

Li Y, Guo G, Yang J, Wei J, Xu J, Cheng C. 2006. Evaluation of antioxidant properties of pomegranate peel extract in comparison on with pomegranate pulp extract. Food Chem. 96, 254-260.

Lovejoy JC, Most MM, Lefevre M, Greenway FL, Rood JC. 2002. Effect of diets enriched in almonds on insulin action and serum lipids in adults with normal glucose tolerance or type 2 diabetes. Am. J. Clin. Nutr. 76, 1000-1006.

Martínez-Valverde I, Periago, MJ, Ros G. 2000. Significado nutricional de los compuestos fenólicos de la dieta. Arch. Lat. Nutr. 50, 5-18.

McBride P, Schrott HG, Plane MB, Underbakke G, Brown RL. 1998. Primary care practice adherence to national cholesterol education program guidelines for patients with coronary heart disease. Arch. Intern. Med. 158, 1238-1244.

Murabito JM, Pencina MJ, Nam BH, D'Agostino RB, Wang TJ, Lloyd JD, Wilson PWF, O'Donnell CJ. 2005. Sibling cardiovascular disease as a risk factor for cardiovascular disease in Middle-aged Adults. J. Am. Me. Assoc. 294, 3117- 3123.

Murray RK, Granner DK, Rodwell VW. 2006. Harper's illustrated biochemistry, $27^{\text {th }}$ ed. McGraw - Hill Education. Casia.

Murthy KN, Jayapeakasha GK, Singh RP. 2002. Studies on antioxidant activity of pomegranate (Pinica granatum) peel extract using in vivo models. J. Agric. Food Chem. 50, 4791-4795.

Nishikimi M, Rao NA, Yagi K. 1972. The occurrence of superoxide anion in the reaction of reduced phenazine methosulfate and molecular oxygen. Biochem. Biophys. Res. Commun. 46, 849-854.

Ohkawa H, Ohnishi N, Yagi K. 1979. Assay for lipid peroxides in animal tissue by thiobarbituric acid reaction. Anal. Biochem. 95, 351-358.

Philip GR, Forrest HN, George CF. 1993. AIN - 76A rodent diet. J. Nutr. 123, 1935-1951.

Reitman S, Frankel S. 1957. A colorimetric method for the determination of serum glutamic oxaloacetic and glutamic pyruvic transaminases. Anal. J. Clin. Pathol. 28, 56-60.
Salama ZA, El-Beltagi HS, El-Hariri DM. 2009. Effect of Fe deficiency on antioxidant system in leaves of three flax cultivars. Not. Bot. Hort. Agrobot. Cluj. 37, 122-128.

SAS Institute 2000. SAS/STAT User's Guide. SAS Institute Inc., Cary and New York.

Schneeman BO, Rico R, Richter BD. 1989. Reduction of plasma and hepatic triglyceride with whole milk containing diet in rats. J. Nutr. 119, 956-970.

Shimelis EA, Rakshit SK. 2007. Effect of processing on antinutrients and in vitro digestibility of kidney beans (Phaseolus vulgaris L.) varities grown in East Africa. Food Chem. 103, 161-172.

Scalbert A, Johnson TI, Saltmarsh M. 2005. Polyphenols: antioxidants and beyond. Am. J. Clin. Nutr. 81, 215S-217S.

Singh RP, Murthy KN, Jayaprakasha GK. 2001. Studies on the antioxidant activity of pomegranate (Pinica granatum) peel and seed extracts using in vitro models. J. Agri. Food Chem. 50, 81-86.

Shehab GMG, Ahmed OK, El-Beltagi HS. 2010. Nitric oxide treatment alleviates drought stress in rice plants (Oryza sativa). Not. Bot. Hort. Agrobot. Cluj. 38, 139-148.

Spencer JP, Schroeter H, Crossthwaithe AJ, Kuhnle G, Williams RT, Rice-Evans C. 2001. Contrasting influences of glucuronidation and O-methylation epicatchin on hydrogen peroxide- induced cell death in neuron and fibroldass. Free Radical. Biol. Med. 31, 1139-1146.

Tharanathan RN, Mahadevamma S. 2003. Grain legumes- a boon to human nutrition. Trends Food Sci. Technol. 14, 507-518.

Tietz NW. 1995. Clinical guide to laboratory tests. 3rd ed. Philadelphia, WB Saunders. 268-273. Trinder P. 1969. Determination of blood glucose using an oxidation peroxides system with a non carcinogenic chromogene. Ann. Clin. Biochem. 6, 24-28

Turnbull F. 2005. Managing cardiovascular risk factors: The gap between evidence and practice PLOS Medicine 2, pp. 374-375

van-Lieshout M, West CE, van-Breemen RB. 2003. Isotope traces techniques for study the bioavailiabity and inefficacy of dietary carotenoids, particularly. Am. J. Clin. Nutr. 7, 12-28

Waller RA, Duncan DB. 1969. A Bayes rule for symmetric multiple comparisons problems. J. Am. Stati. Assoc. 64, 1484-1503.

Wang Y, Jones P. 2004. Dietary conjugated linolic acid and body composition. Am. J. Clin. Nutr. 79, 11531158.

Warnick GR, Benderson J, Albers JJ. 1983. Selected Methods. Clin. Chem. 10, 91-99.

World Health Reports 2002. Reducing risks. Promoting healthy like. 1-239. 